\title{
Antiproliferative Effects of Alkaloids from the Bulbs of Crinum abyscinicum Hochst. ExA. Rich
}

\author{
Besufekad Abebe, Solomon Tadesse $(\mathbb{D}$, Ariaya Hymete, and Daniel Bisrat $\mathbb{D}$ \\ Department of Pharmaceutical Chemistry and Pharmacognosy, School of Pharmacy, Addis Ababa University, P.O. Box 1176, \\ Addis Ababa, Ethiopia \\ Correspondence should be addressed to Daniel Bisrat; daniel.bisrat@aau.edu.et
}

Received 1 August 2020; Revised 7 October 2020; Accepted 16 October 2020; Published 31 October 2020

Academic Editor: Gourav Dey

Copyright (c) 2020 Besufekad Abebe et al. This is an open access article distributed under the Creative Commons Attribution License, which permits unrestricted use, distribution, and reproduction in any medium, provided the original work is properly cited.

\begin{abstract}
Crinum abyscinicum Hochst. ExA. Rich bulb is traditionally used in Ethiopia for the treatment of various ailments including internal parasites, mastitis, rabies, colic diseases of animals, and cancer. Despite its importance in traditional cancer treatment, no research work has been reported on the antiproliferative activity of the bulb extract and its major constituents. Phytochemical investigation of the bulb extract of C. abyscinicum by PTLC over silica gel resulted in the isolation of two alkaloids, which were unequivocally identified as 6-hydroxycrinamine and lycorine on the basis of ${ }^{1} \mathrm{H}$ - and ${ }^{13} \mathrm{C}-\mathrm{NMR}$ and MS analysis. The bulb extract, 6-hydroxycrinamine, and lycorine possessed significant antiproliferative activity, lycorine being the most active exhibiting $\mathrm{GI}_{50}$ values of $2.8 \mu \mathrm{g} / \mathrm{ml}$ and $3.4 \mu \mathrm{g} / \mathrm{ml}$ against A2780 and MV4-11 cells, respectively. Cell cycle analysis and annexin V/propidium iodide double staining in A2780 cells revealed that both compounds increased the percentage of cells in the S-phase at $30 \mu \mathrm{g} / \mathrm{ml}$ without inducing apoptosis. Our results suggest that the antiproliferative activities of the bulb extract of C. abyscinicum, 6hydroxycrinamine, and lycorine could support the traditional claim of the plant against cancer.
\end{abstract}

\section{Introduction}

Cancer is the second leading cause of death worldwide, accounting for an estimated 9.6 million deaths globally in 2018 [1]. In fact, approximately 70\% of deaths from cancer occurred in low- and middle-income countries, of which Africa accounted for $7.3 \%$ of the total cancer deaths in 2018 [1]. The low cancer death reports in Africa could be due to the lack of accurate and population-based data in many of the countries $[2,3]$.

Most often, cancer treatment involves combination therapy, such as surgery, radiotherapy, and chemotherapy. However, high toxicity and high cost associated with monotargeted therapies have encouraged researchers to look for alternative approaches [4]. The use of chemicals from plant extracts offers a compelling rationale for addressing the underlying biology of cancer while being efficacious, nontoxic, and cost-effective [5].

Natural products have been a rich source of medicine [6]. The huge structural diversity of natural compounds and their potential bioactivity have meant that several compounds isolated from natural sources can serve as "lead" compounds. For instance, approximately $75 \%$ of anticancer agents marketed from 1981 to 2006 were obtained or semisynthesized from plants [7]. Anticancer drugs such as vinblastine, vincristine, vinorelbine, and paclitaxel, as well as semisynthetic agents including docetaxel, camptothecin, topotecan, and irinotecan, are isolated from plants and microbes $[8,9]$. The genus Crinum belongs to the family Amaryllidaceae and comprises approximately 130 species throughout the tropics and warm temperate regions of the world [10]. Indeed, over 500 different kinds of Amaryllidaceae alkaloids (AAs) have been found in the family Amaryllidaceae [11, 12]. Several alkaloids of the Amaryllidaceae type present in Crinum species are reported to exert antitumor, immunostimulating, analgesic, antiviral, antibacterial, and antifungal effects [13].

Ethiopia, like many other developing countries, heavily relies on the therapeutic benefits of traditional medicine to treat diseases $[14,15]$. C. abyscinicum bulb powder mixed 
with hyena feces is applied topically for the treatment of cancer, locally called "neqersa," in Dek Island in Lake Tana, Ethiopia [14]. Ovarian cancer is the third leading cause of cancer death among women in Ethiopia, with about 2,550 diagnosed cases and 2,000 deaths each year, while leukemia is the leading cancer incident $(2,274,10.7 \%$ of new cancer cases) in Ethiopia among men of all ages in 2018 [16, 17]. Thus, in the present study, we used A2780 and MV4-11 cells to examine the antiproliferative potential of the C. abyscinicum bulb extract and its two alkaloids, 6hydroxycrinamine and lycorine. In addition, we explored the anticancer mechanisms of 6-hydroxycrinamine and lycorine by using the flow cytometer. To the best of our knowledge, no prior chemical and biological investigation has been reported on C. abyscinicum.

\section{Materials and Methods}

2.1. Collection of the Plant Material. The bulb of C. abyscinicum (1 kg) (Figure 1) was collected from the town of Alelitu, $44 \mathrm{~km}$ northeast of Addis Ababa, in April 2015. The authenticity of the plant was confirmed by Mr. Melaku Wondafrash, Senior Botanist at the National Herbarium, Addis Ababa University (AAU), where specimens were deposited with collection number BA0001.

2.2. Instruments. High-resolution mass spectra acquisition was performed with an AB SCIEX Triple TOF $5600^{+}$mass spectrometer (Concord, ON, Canada) in the positive ion mode using the following parameters: source temperature was set at $450^{\circ} \mathrm{C}$ with a curtain gas flow of $25 \mathrm{~L} / \mathrm{min}$ (GS1 and GS2 both 50), the ion spray voltage was set at $4500 \mathrm{~V}$, declustering potential was $50 \mathrm{~V}$, the collision energy was $10 \mathrm{~V}$, and the mass range was set at $m / z 50-1500$. Highpurity nitrogen gas was used for the nebulizer/Duospray ${ }^{\mathrm{TM}}$ and curtain gases. MS data acquired were processed using Analyst ${ }^{\circledR}$ TF software. Prior to MS, the sample was dissolved in methanol $(1 \mathrm{mg} / \mathrm{ml})$ and used for all sample injections. ${ }^{1} \mathrm{H}$ - and ${ }^{13} \mathrm{C}-\mathrm{NMR}$ spectra were obtained using a Bruker Avance III HD spectrometer (Faellanden, Switzerland) at 500 and $125 \mathrm{MHz}$, respectively. The 2D experiments carried out included heteronuclear multiple-quantum correlation (HMQC) and heteronuclear multiple-bond correlation (HMBC). Chemical shifts are reported in units of $\delta(\mathrm{ppm})$, and coupling constants $(J)$ are expressed in Hz. Multiplicity of ${ }^{1} \mathrm{H}-\mathrm{NMR}$ signals is reported as $s=$ singlet, $d=$ doublet, $t=$ triplet,$q=$ quartet,$d d=$ doublet of doublets, and $m=$ multiplet.

2.3. Extraction and Isolation of Compounds. Dried powdered bulbs of C. abyscinicum (200 g) were macerated in $80 \%$ methanol $(3 \times 2 \mathrm{~L}, 72 \mathrm{~h}$ each). Then, the solution was filtered, concentrated under reduced pressure using a rota evaporator, and finally dried by a freeze drier to yield $16.3 \mathrm{~g}$ extract. Analytical thin-layer chromatography (TLC) was used to select a solvent system with a better resolution of the constituents of the crude drug as well as to monitor the purity of the isolated compounds. Consequently, from series of solvent systems, butanol: acetic acid: water $(4: 1: 5)$ was selected as a mobile phase. The solvent was prepared by dissolving butanol, water, and then adding acetic acid. Because the solvent forms two phases, the upper layer was taken and used as a solvent system for the chromatographic separation. The extract was initially dissolved in methanol and directly applied to PTLC plates over silica gel $60 \mathrm{~F}_{254}$ plates (aluminium plate, $200 \mu \mathrm{m}$, Merck KGaA, Darmstadt, Germany), and the separation was achieved using a mobile phase used for analytical chromatography. After the development, the bands were visualized under UV light at 254 and $366 \mathrm{~nm}$. Two bands named BCA-1 and BCA-2 were separately scrapped off and washed with a mixture of ethyl acetate and methanol $(1: 1)$, filtered, and concentrated to offer two alkaloids (Figure 2) with the $R_{f}$ value of 0.62 BCA-1 ((6-hydroxycrinamine) (1), $12 \mathrm{mg})$ and (0.44 BCA-2 (lycorine) (2), $25 \mathrm{mg}$ ).

2.4. Cell Lines and Culture Conditions. MV4-11 (human acute myeloid leukemia; American Type Culture Collection (ATCC)) and A2780 (ovarian cancer; European Collection of Authenticated Cell Cultures (ECACC)) cells were obtained from the cell bank at the Centre for Drug Discovery and Development, University of South Australia. The cell lines were maintained following ATCC recommendations either in RPMI-1640 (Roswell Park Memorial Institute), DMEM (Dulbecco's Modified Eagle's Medium), or MEM (Minimum Essential Media) with 10\% fetal bovine serum. All cell lines were cultured at $37^{\circ} \mathrm{C}$ in a humidified incubator in the presence of $5 \% \mathrm{CO}_{2}$. All cells were mycoplasma-tested.

2.5 . Antiproliferative

Assay.

3-(4,5-Dimethylthiazol-2-yl)-2,5-diphenyltetrazolium bromide (MTT) assay was carried out on A2780 cell lines as described elsewhere [18]. In brief, $1 \times 10^{5}$ cells/well were seeded into 96 -well plates and incubated overnight at $37^{\circ} \mathrm{C}$. Test samples were dissolved in dimethyl sulfoxide (DMSO), and a 3 -fold dilution series was prepared in $100 \mu \mathrm{L}$ of the cell medium, added to cells (in duplicates), and incubated for $72 \mathrm{~h}$ at $37^{\circ} \mathrm{C}$. MTT was made up as a stock of $5 \mathrm{mg} / \mathrm{mL}$ in the cell medium, and the solution was filter-sterilized. Medium was removed from cells followed by washing with $200 \mu \mathrm{L} /$ well phosphate-buffered saline. MTT solution was then added at $20 \mu \mathrm{L} /$ well and incubated in the dark at $37^{\circ} \mathrm{C}$ for $4 \mathrm{~h}$. MTT solution was removed, and cells were again washed with $200 \mu \mathrm{L}$ of PBS. MTT dye was solubilized with $200 \mu \mathrm{L} /$ well of DMSO with agitation. Absorbance was read at $540 \mathrm{~nm}$ using an EnVision multilabel plate reader (PerkinElmer, Beaconsfield, Buckinghamshire, UK).

Resazurin assay was done on MV4-11 cell lines as described previously [19]. In short, cells were seeded at $5 \times 10^{3}$ cells/well into 96-well plates and incubated overnight at $37^{\circ} \mathrm{C}, 5 \% \mathrm{CO}_{2}$. Tested samples were diluted from $10 \mathrm{mM}$ stock solution to prepare a threefold dilution series in $100 \mathrm{~mL}$ of the cell medium, added to cells (in duplicates), and incubated at the corresponding time point at $37^{\circ} \mathrm{C}, 5 \%$ $\mathrm{CO}_{2}$. Resazurin was made up as a stock of $0.1 \mathrm{mg} / \mathrm{mL}$ in the cell medium, and the solution was filter-sterilized. The 


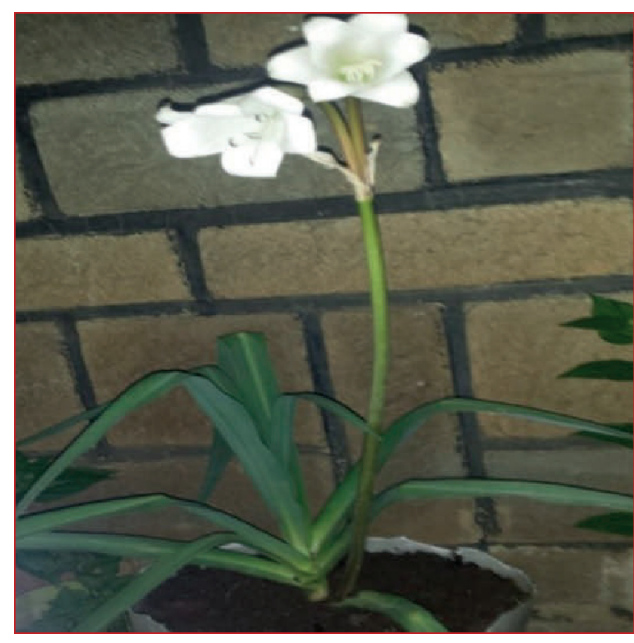

(a)

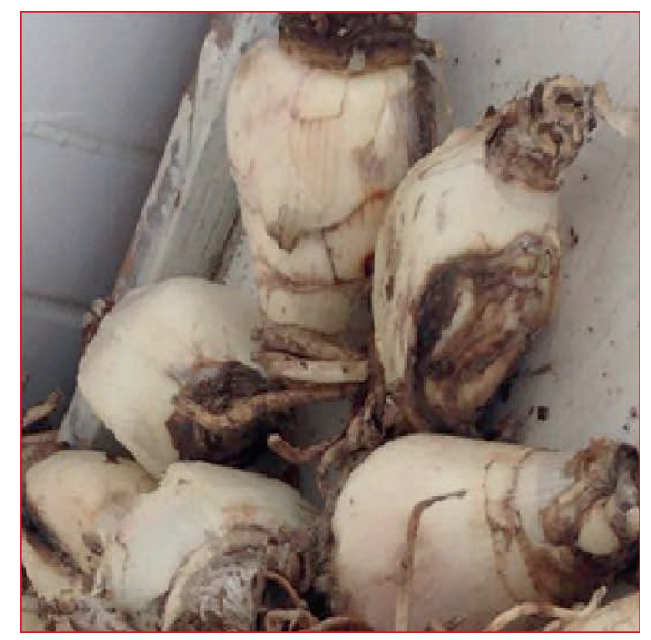

(b)

Figure 1: Crinum abyscinicum: (a) whole plant; (b) bulbs.

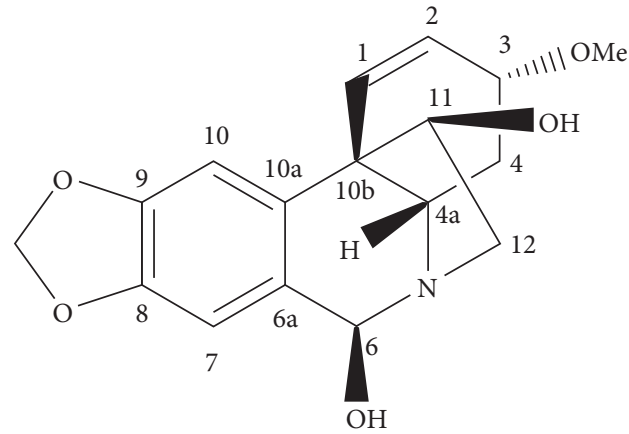

6-Hydroxycrinamine (1)

(a)

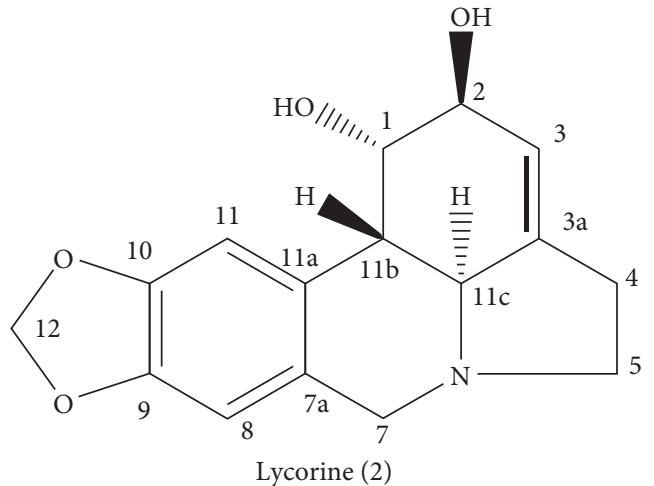

(b)

FIgURE 2: Structural formulae of alkaloids isolated from the bulbs of Crinum abyscinicum. (a) 6-Hydroxycrinamine (1). (b) Lycorine (2).

resazurin solution was then added at $20 \mu \mathrm{L} /$ well and incubated in the dark at $37^{\circ} \mathrm{C}, 5 \% \mathrm{CO}_{2}$, for $4 \mathrm{~h}$. The plate was left at room temperature for $10-15 \mathrm{~min}$, and absorbance was measured at $585 \mathrm{~nm}$ using an EnVision multilabel plate reader (PerkinElmer, Beaconsfield, Buckinghamshire, UK). The concentration of the bulb extract of C. abyscinicum and isolated compounds required to inhibit $50 \%$ of cell growth $\left(\mathrm{GI}_{50}\right)$ was calculated using nonlinear regression analysis.

2.6. Cell Cycle Analysis. Cell cycle analysis was performed as described elsewhere [20]. Cells were seeded at $8 \times 10^{4}$ cells per well using a 6-well plate and incubated overnight at $37^{\circ} \mathrm{C}$, $5 \% \mathrm{CO}_{2}$. After treatment with each compound, the cells were incubated for $24 \mathrm{~h}$. Cells were transferred to fluorescenceactivated cell sorting (FACS) tubes and centrifuged at $300 \mathrm{~g}$ for $5 \mathrm{~min}$. Cell pellets were collected and resuspended in $1 \mathrm{~mL}$ of phosphate-buffered saline (PBS) and centrifuged at $300 \mathrm{~g}$ for $5 \mathrm{~min}$. Supernatant PBS was removed, and cell pellets were fixed by adding $500 \mu \mathrm{L}$ ice-cold $70 \%$ ethanol dropwise on ice for $15 \mathrm{~min}$ and collected again after being centrifuged at $300 \mathrm{~g}$ for $5 \mathrm{~min}$. Supernatant ethanol was removed, and collected pellets were incubated with propidium iodide cell cycle solution in PBS $(50 \mu \mathrm{g} / \mathrm{mL}$ propidium iodide, $0.1 \mathrm{mg} / \mathrm{mL}$ RNase A, and $0.05 \%$ Triton X-100) at room temperature for $1.5 \mathrm{~h}$ and analyzed with a Gallios flow cytometer (Beckman Coulter, Brea, CA, USA). Data were analyzed using Kaluza v1.2 (Beckman Coulter, Brea, CA, USA).

2.7. Apoptosis Assay. Apoptotic induction test was performed as described previously [20]. Cells were seeded at $8 \times 10^{4}$ cells per well using a 6-well plate and incubated overnight at $37^{\circ} \mathrm{C}, 5 \% \mathrm{CO}_{2}$. After treatment with each compound, the cells were incubated for $24 \mathrm{~h}$. Cells were transferred to FACS tubes and centrifuged at $300 \mathrm{~g}$ for $5 \mathrm{~min}$. Cell pellets were collected and resuspended in $1 \mathrm{~mL}$ of warm PBS and centrifuged at $300 \mathrm{~g}$ for $5 \mathrm{~min}$. Supernatant PBS was removed, and cell pellets were diluted to $1 \times 10^{5}$ cells $/ \mathrm{mL}$ with warm PBS and centrifuged at $300 \mathrm{~g}$ for $5 \mathrm{~min}$. Supernatant PBS was removed, and cell pellets were resuspended with $1 \mathrm{~mL}$ of ice-cold PBS and centrifuged at $300 \mathrm{~g}$ for $5 \mathrm{~min}$. Supernatant PBS was removed, and cell pellets were 
resuspended with $100 \mu \mathrm{L}$ of $1 \times$ binding buffer. Then, $3 \mu \mathrm{L}$ of annexin $\mathrm{V}$ and $3 \mu \mathrm{L}$ of propidium iodide were added to each sample with slight vortexing, and cells were incubated in the dark for $15 \mathrm{~min}$. After incubation, $200 \mu \mathrm{L}$ of $1 \times$ binding buffer was added to each sample and analyzed by the Gallios flow cytometer (Beckman Coulter, Brea, CA, USA). Data were analyzed using Kaluza v1.2 (Beckman Coulter, Brea, CA, USA).

2.8. Statistical Analysis. All experiments were performed in triplicate and repeated at least twice and were given as mean $\pm \mathrm{SD}$; representative data were selected for generating figures.

\section{Results}

3.1. Characterization of Isolated Compounds. Phytochemical investigation of the $80 \%$ methanol extract of C. abyscinicum bulbs by PTLC afforded two compounds, with $R_{f}$ values of 0.62 (compound 1) and 0.44 (compound 2) (mobile phase: $\left.n-\mathrm{BuOH} / \mathrm{H}_{2} \mathrm{O} / \mathrm{AcOH} / 4: 5: 1\right)$. Compounds 1 and 2 produced orange colour when sprayed with Dragendorff's reagent (a solution of potassium bismuth iodide prepared from basic bismuth nitrate $\left.\left(\mathrm{Bi}\left(\mathrm{NO}_{3}\right)_{3}\right)\right)$, tartaric acid, and potassium iodide (KI), suggesting that they are alkaloids [21].

Compound 1 was isolated as a pale green colored amorphous solid with a pseudo-molecular ion at $\mathrm{m} /$ $z=318.1619[\mathrm{M}+\mathrm{H}]^{+}$in the positive-mode HR-TOF-ESIMS (Figure S1), indicating a molecular formula of $\mathrm{C}_{17} \mathrm{H}_{19} \mathrm{NO}_{5}$ for compound 1. A close analysis of the spectral data of compound 1 revealed that its ${ }^{1} \mathrm{H}$ - (Figure S2) and ${ }^{13} \mathrm{C}-\mathrm{NMR}$ spectra (Figures S3 and S4) were identical with those of previously reported for 6-hydroxycrinamine (see in the following), a compound isolated from the ethanolic extract of Crinum bulbispermum [22]. It was also reported to be present in the leaves of Crinum yemense [23]. Furthermore, the structure of compound 1 (Figure 2) was further confirmed by $2 \mathrm{D}-\mathrm{NMR}$, particularly by the long-range couplings between $\mathrm{C}$ and $\mathrm{H}$ observed in HMBC.

Compound 2 was obtained as a yellow colored amorphous solid. A molecular formula of $\mathrm{C}_{16} \mathrm{H}_{17} \mathrm{NO}_{4}$ for compound 2 was deduced from the positive-mode HR-TOF-ESI-MS $(\mathrm{m} / z$ : 288.1176 $\left.[\mathrm{M}+\mathrm{H}]^{+}\right)$(Figure S5). Based on its $1 \mathrm{D}\left({ }^{1} \mathrm{H}\right.$ and $\left.{ }^{13} \mathrm{C}\right)$ (Figures S6-S8) and 2D (HMBC and HMQC) spectral data, compound 2 was unambiguously characterized as lycorine (Figure 2) [22, 24, 25]. Lycorine is the first and the most abundant alkaloid reported from the genus and the family Amaryllidaceae [26, 27].

3.1.1. Spectral Data for Compounds 1 and 2. 6-Hydroxycrinamine (BCA-1) (1): a pale green colored amorphous solid; $R_{f}=0.62\left(n-\mathrm{BuOH} / \mathrm{H}_{2} \mathrm{O} / \mathrm{AcOH}-4: 5: 1\right)$; HR-TOF-ESI-MS (+ve mode, Figure S1) $\mathrm{m} / z$ : 318.1619 $[\mathrm{M}+\mathrm{H}]^{+}\left(\right.$exact calcd. 318.1341 for $\left.[\mathrm{M}+\mathrm{H}]^{+}\right)$indicating a molecular formula of $\mathrm{C}_{17} \mathrm{H}_{19} \mathrm{NO}_{5} ;{ }^{1} \mathrm{H}-\mathrm{NMR}(500 \mathrm{MHz}$, MeOD, Figure S2) $\delta: 2.35(2 \mathrm{H}, m, \mathrm{H}-4), 3.16(2 \mathrm{H}, d d, \mathrm{H}-12)$, $3.45(3 \mathrm{H}, s, \mathrm{O}-\mathrm{Me}), 3.52(1 \mathrm{H}, m, \mathrm{H}-4 \mathrm{a}), 3.88$ (1H, $m, \mathrm{H}-11)$,
$4.09(1 \mathrm{H}, m, \mathrm{H}-3), 5.50(1 \mathrm{H}, s, \mathrm{H}-6), 5.92\left(2 \mathrm{H}, s, \mathrm{O}-\mathrm{CH}_{2}-\mathrm{O}\right)$, $6.11(1 \mathrm{H}, d, \mathrm{H}-2), 6.31(1 \mathrm{H}, d, \mathrm{H}-1), 6.78(1 \mathrm{H}, s, \mathrm{H}-10), 6.86$ $(1 \mathrm{H}, s, \mathrm{H}-7) ;{ }^{13} \mathrm{C}-\mathrm{NMR}(125 \mathrm{MHz}, \mathrm{MeOD}$, Figures S3 and S4) $\delta: 29.03$ (C-4), 50.41 (C-10b), $54.40\left(\mathrm{O}-\mathrm{CH}_{3}\right), 57.56(\mathrm{C}-12)$, 59.96 (C-4a), 76.49 (C-3), 78.23 (C-11), 87.57 (C-6), 101.03 (O-CH$\left.-\mathrm{CH}_{2}-\mathrm{O}\right), 102.36$ (C-10), 108.89 (C-7), 124.38 (C-2), 127.89 (C-6a), 132.94 (C-1), 137.16 (C-10a), 146.30 (C-8), 147.88 (C-9).

Lycorine (BCA-2) (2): a yellow colored amorphous solid; $R_{f}=0.44\left(n-\mathrm{BuOH} / \mathrm{H}_{2} \mathrm{O} / \mathrm{AcOH}-4: 5: 1\right) ; \mathrm{HR}-\mathrm{TOF}-\mathrm{ESI} \mathrm{MS}$ (+ve mode, Figure S5) $m / z: 288.1176[\mathrm{M}+\mathrm{H}]^{+}$(exact calcd. 288.1236 $[\mathrm{M}+\mathrm{H}]^{+}$) indicating a molecular formula of $\mathrm{C}_{16} \mathrm{H}_{17} \mathrm{NO}_{4} ;{ }^{1} \mathrm{H}-\mathrm{NMR}(500 \mathrm{MHz}, \mathrm{MeOD}$, Figure S6) $\delta: 2.38$ (1H, $m, \mathrm{H}-5 \mathrm{~b}), 2.46$ (2H, $m, \mathrm{H}-4), 2.62$ (1H, $m, \mathrm{H}-11 \mathrm{~b}), 2.71$ (1H, brs, H-11c), 2.90 (1H, $d, \mathrm{H}-5 \mathrm{a}), 3.54$ (1H, $d, \mathrm{H}-7 \mathrm{~b}), 4.13$ $(1 \mathrm{H}, d, \mathrm{H}-7 \mathrm{a}), 4.19(1 \mathrm{H}, s, \mathrm{H}-2), 4.48(1 \mathrm{H}, s, \mathrm{H}-1), 5.56(1 \mathrm{H}, s$, $\mathrm{H}-3), 5.93\left(2 \mathrm{H}, s, \mathrm{O}-\mathrm{CH}_{2}-\mathrm{O}\right), 6.66(1 \mathrm{H}, s, \mathrm{H}-11), 6.90(1 \mathrm{H}, s$, $\mathrm{H}-8) ;{ }^{13} \mathrm{C}-\mathrm{NMR}(125 \mathrm{MHz}, \mathrm{MeOD}$, Figures S7 and S8) $\delta$ : 27.91 (C-4), 39.96 (C-11b), 53.30 (C-7), 56.42 (C-5), 61.05 (C-11c), 70.56 (C-1), 71.74 (C-2), $100.89\left(\mathrm{O}-\mathrm{CH}_{2}-\mathrm{O}\right), 104.63$ (C-11), 106.81 (C-8), 117.76 (C-3), 128.36 (C-11a), 128.99 (C-7a), 142.31 (C-3a), 146.29 (C-10), 146.77 (C-9).

3.2. Antiproliferative Activity. To evaluate the antiproliferative activity of the bulbs of C. abyscinicum, its $80 \%$ methanol extract was tested against A2780 and MV4-11 cell lines using MTT and resazurine assays, respectively. The results indicated that the bulb extract exerted antiproliferative effect against MV4-11 $\left(\mathrm{GI}_{50}=8.3 \mu \mathrm{g} / \mathrm{ml}\right)$ and A2780 $\left(\mathrm{GI}_{50}=20.8 \mu \mathrm{g} / \mathrm{ml}\right)$ cell lines. Thus, the bulb extract of C. abyscinicum possesses a promising anticancer potential. In the United States National Cancer Institute plant screening program, a crude extract is generally considered to have in vitro cytotoxic activity if the $\mathrm{IC}_{50}$ value following incubation between 48 and $72 \mathrm{~h}$ is less than $30 \mu \mathrm{g} / \mathrm{mL}$ [28].

Due to the promising antiproliferative activity of the C. abyscinicum bulb extract and in an attempt to identify its active ingredient, we determined the antiproliferative effects of both 6-hydroxycrinamine and lycorine against the same cancer cell lines. The results are summarized in Table 1. 6-Hydroxycrinamine is active against A2780 $\left(\mathrm{GI}_{50}=2.9 \mu \mathrm{g} /\right.$ $\mathrm{ml})$ and MV4-11 $\left(\mathrm{GI}_{50}=5.3 \mu \mathrm{g} / \mathrm{ml}\right)$ cells. Lycorine showed better activity against both A2780 $\left(\mathrm{GI}_{50}=2.8 \mu \mathrm{g} / \mathrm{ml}\right)$ and MV4-11 $\left(\mathrm{GI}_{50}=3.4 \mu \mathrm{g} / \mathrm{ml}\right)$ cells when compared with the bulb extract and 6-hydroxycrinamine (Table 1).

3.3. Effects on Cell Cycle and Induction of Apoptosis. A2780 cell line, being more sensitive to both compounds (6hydroxycrinamine and lycorine), was selected for further mechanistic studies to determine whether the growth inhibitory activity of both compounds was related to cell cycle arrest and/or induction of apoptosis. 6-Hydroxycrinamine $(3 \mu \mathrm{g} / \mathrm{ml})$ resulted in the increase in the percentage of A2780 cells in the G2/M-phase from $12.46 \%$ to $16.62 \%$, accompanied by a corresponding decrease in the G1- and S-phase in A2780 cells (Figure 3), whereas at higher doses $(30 \mu \mathrm{g} / \mathrm{ml})$, lycorine increased the S-phase cell count from $14.54 \%$ to 
TABLE 1: Antiproliferative activity of the bulb extract of Crinum abyscinicum, 6-hydroxycrinamine, and lycorine against A2780 and MV4-11 cell lines.

\begin{tabular}{lcc}
\hline Sample name & & $\mathrm{GI}_{50}(\mu \mathrm{g} / \mathrm{ml} \pm \mathrm{SD})$ \\
\hline Bulb extract & $\mathrm{A} 2780$ & $\mathrm{MV} 4-11$ \\
6-Hydroxycrinamine (1) & $20.8 \pm 0.4$ & $8.3 \pm 0.3$ \\
Lycorine (2) & $2.9 \pm 0.8$ & $5.3 \pm 0.5$ \\
Palbociclib & $2.8 \pm 0.1$ & $3.4 \pm 0.3$ \\
\hline
\end{tabular}

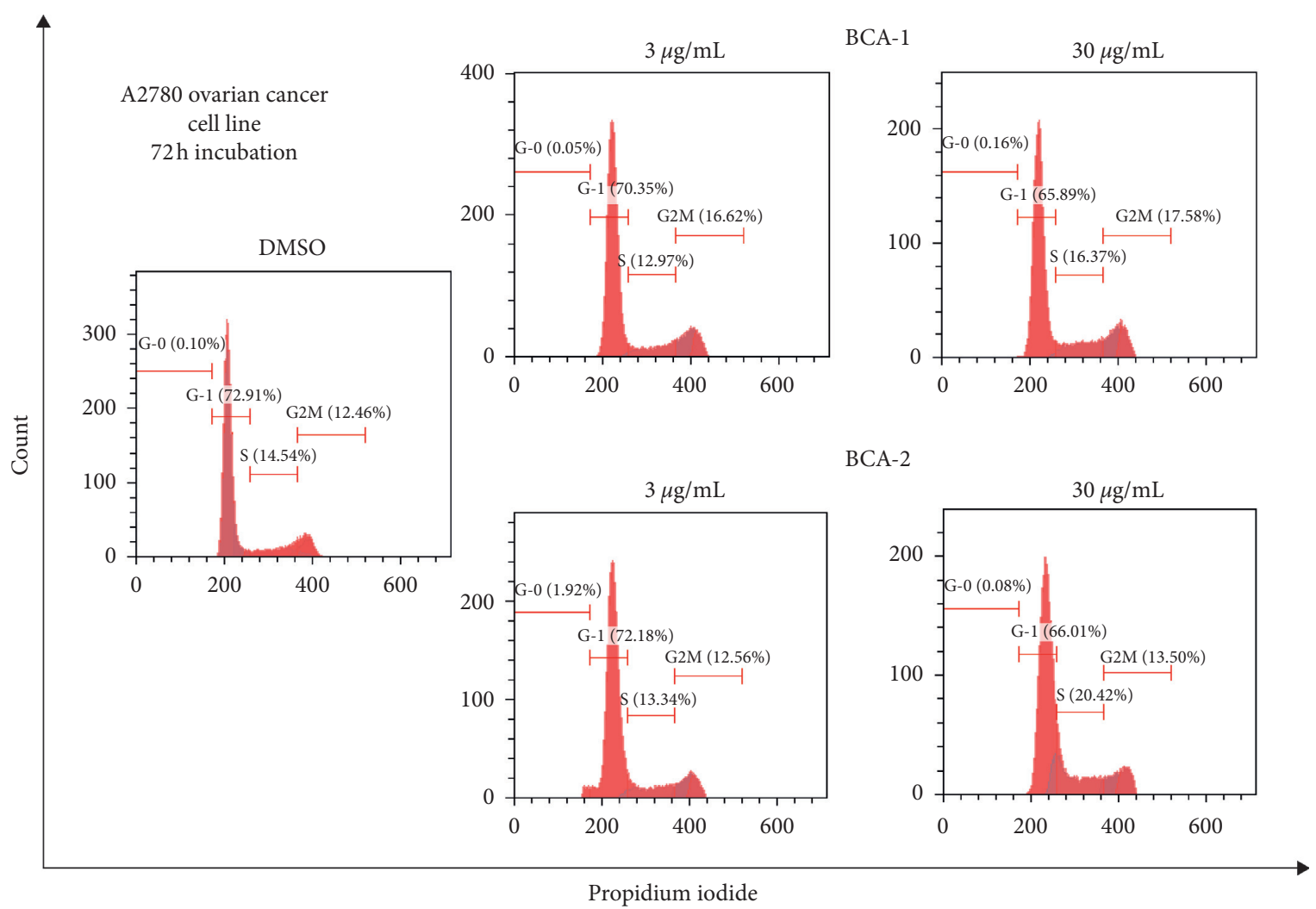

FIGURE 3: 6-Hydroxycrinamine (BCA-1) causes G2/M-phase arrest at $3 \mu \mathrm{g} / \mathrm{ml}$ and lycorine (BCA-2) causes S-phase arrest at $30 \mu \mathrm{g} / \mathrm{ml}$ on the cell cycle of A2780 cells.

$20.42 \%$. The observed cell cycle effects of the compounds are similar to the effects of cisplatin on A2780 cells [29].

To determine whether apoptosis contributes to the observed antiproliferative effects of 6-hydroxycrinamine and lycorine, annexin $\mathrm{V} /$ propidium iodide double staining of A2780 was used. Both 6-hydroxycrinamine and lycorine did not induce apoptosis (Figure 4).

\section{Discussion}

Several studies have demonstrated that the genus Crinum belonging to the Amaryllidaceae family continue to yield alkaloids having interesting biological activities [13, 30]. For example, galanthamine is used for symptomatic treatment of Alzheimer disease [31], crinine and 6-ethoxybuphandrine exhibited anticancer effect [32], and cripowellin A, B, C, and $\mathrm{D}$ have antiplasmodial activity [33]. In the present study, 6hydroxycrinamine and lycorine have been found in the bulb extract of C. abyscinicum, a plant which is important in
Ethiopian traditional medicine [14]. It is noted that lycorine showed better activity against both $\mathrm{A} 2780\left(\mathrm{GI}_{50}=2.8 \mu \mathrm{g} / \mathrm{ml}\right)$ and MV4-11 $\left(\mathrm{GI}_{50}=3.4 \mu \mathrm{g} / \mathrm{ml}\right)$ cells when compared with the bulb extract $\left(\mathrm{GI}_{50}=8.3 \mu \mathrm{g} / \mathrm{ml}\right.$, MV4-11, and $\mathrm{GI}_{50}=20.8 \mu \mathrm{g} / \mathrm{ml}, \quad$ A2780) and 6-hydroxycrinamine $\left(\mathrm{GI}_{50}=2.9 \mu \mathrm{g} / \mathrm{ml}, \mathrm{A} 2780\right.$, and $\left.\mathrm{GI}_{50}=5.3 \mu \mathrm{g} / \mathrm{ml}, \mathrm{MV} 4-11\right)$ cells.

Lycorine has been reported to possess in vitro anticancer activities against ovarian carcinoma cell line (SK-OV-3) with an $\mathrm{IC}_{50}$ value of $0.86 \mu \mathrm{g} / \mathrm{ml}$ [31]. Lycorine has also displayed inhibitory properties towards various cancer cell lines including lymphoma, multiple myeloma, melanoma, leukemia, lung cancer, esophageal cancer, and human anaplastic oligodendroglioma [31].

6-Hydroxycrinamine was also reported to be cytotoxic against human pancreatic (PANC1, $\mathrm{IC}_{50}=7.20 \mu \mathrm{g} / \mathrm{ml}$ ) and prostate (DU145, IC $\mathrm{IC}_{50}=2.95 \mu \mathrm{g} / \mathrm{ml}$ ) cancer cells [32]. Structurally similar compounds to 6-hydroxycrinamine such as haemanthamine and haemanthidine were also found 


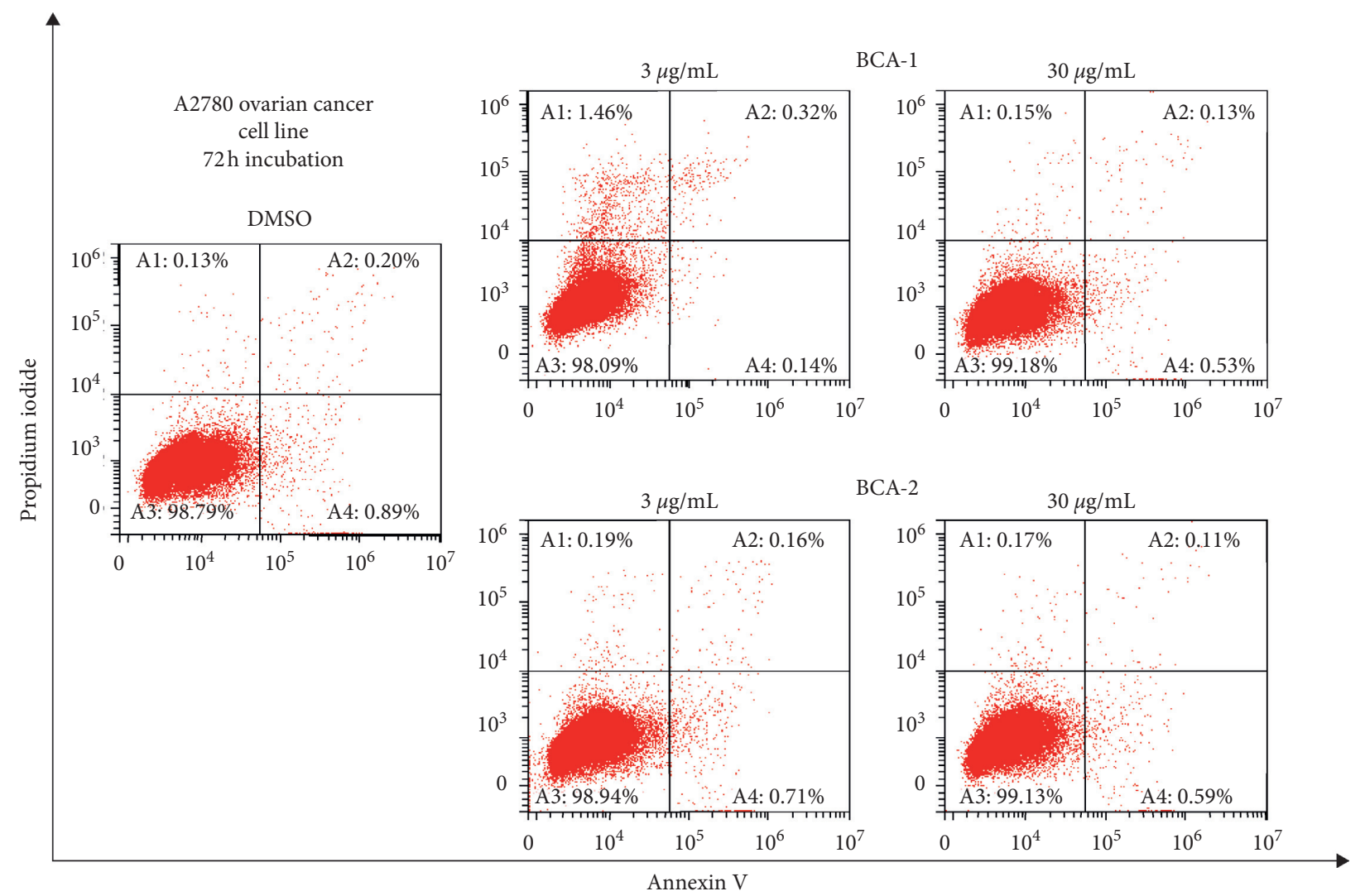

FIgURE 4: Effects of 6-hydroxycrinamine (BCA-1) and lycorine (BCA-2) on the induction of apoptosis. A1: necrotic cells, A2: cell in late apoptosis, A3: viable cells, and A4: cells at early apoptosis. BCA-1 and BCA-2 did not induce apoptosis at $3 \mu \mathrm{g} / \mathrm{ml}$ and $30 \mu \mathrm{g} / \mathrm{ml}$ on A2780 cells.

to exert antiproliferative activity against similar cell line A2780 with a lower $\mathrm{IC}_{50}$ value of $215.78 \mu \mathrm{g} / \mathrm{ml}$ and $452.01 \mu \mathrm{g} /$ $\mathrm{ml}$, respectively [13], while crinamine which lacks 6-hydroxy substitute showed anticancer activity against HPV-positive cervical carcinoma SiHa $\left(\mathrm{IC}_{50}=7.09 \mu \mathrm{g} / \mathrm{ml}\right)$ and HPV-negative cervical carcinoma C33a (IC50 $=18.35 \mu \mathrm{g} / \mathrm{ml}$ ) cells as well as induced apoptosis without causing DNA damage [33].

Cell cycle analysis and annexin V/propidium iodide double staining in A2780 cells revealed that both compounds increased the percentage of cells in the S-phase at $30 \mu \mathrm{g} / \mathrm{ml}$ without inducing apoptosis. The observed cell cycle effects of both compounds are similar to the effects of cisplatin on A2780 cells [29]. A2780 cells exposed to cisplatin accumulated in the G2/M-phase at $0.3 \mu \mathrm{g} / \mathrm{ml}$ and $0.6 \mu \mathrm{g} / \mathrm{ml}$ drug concentrations. Concomitant decreases in S- and G1phase populations were also observed, but higher concentrations increased the relative distribution of cells in the S-phase. These events in the S- and G2/M-phase were associated with checkpoint kinases (chk1 and chk2)activation, and resultant phosphorylation and proteosomal degradation of cell division cycle $25 \mathrm{~A}$ (Cdc25 A). Both 6-hydroxycrinamine and lycorine did not induce apoptosis. Thus, it is possible that other mechanisms could be involved in the antiproliferative effect of the compounds. In some drugresistant ovarian cancer cell lines such as Hey1B, antiproliferative activity was associated with induction of cytostatic effects through increasing rigidity of the actin cytoskeleton [34, 35]. However, we were unable to determine the effect of the compounds on nonmalignant cells due to their unavailability in our laboratory at the time of the study. We therefore strongly recommend further studies aiming at determining the selectivity index of 6-hydroxycrinamine and lycorine.

\section{Conclusions}

In this study, two alkaloids, 6-hydroxycrinamine and lycorine, were isolated from C. abyscinicum, and their anticancer activities were evaluated. Promising antiproliferative activity was established for 6-hydroxycrinamine and lycorine against A2780 epithelial ovarian cancer and MV4-11 acute myeloid leukemia cell lines. 6-Hydroxycrinamine and lycorine promote cell cycle arrest in A2780 cells without inducing apoptosis.

\section{Data Availability}

All the data used to support the findings of this study are included within the article and in the supplementary information files.

\section{Conflicts of Interest}

The authors declare no conflicts of interest. 


\section{Authors' Contributions}

BA, ST, DB, AH contributed to conception, overall study design, writing, reviewing, and/or revision of the manuscript. BA was responsible for plant collection, extraction, and isolation of compounds. BA, ST, and DB contributed to data analysis. BT performed biological experiments. All authors read and approved the final manuscript.

\section{Acknowledgments}

The authors would like to gratefully acknowledge Professor Shudong Wang for allowing ST to use the facilities at the University of South Australia and the National Herbarium at Addis Ababa University for identification of the plant material.

\section{Supplementary Materials}

Figure S1: +ve mode-HR-TOF-ESI-mass spectrum of 6hydroxycrinamine (1). Figure $S 2:{ }^{1} \mathrm{H}-\mathrm{NMR}$ spectrum of 6hydroxycrinamine (1). Figure $\mathrm{S} 3:{ }^{13} \mathrm{C}$-NMR spectrum of 6-hydroxycrinamine (1). Figure S4: DEPT-135 spectrum of 6-hydroxycrinamine (1). Figure S5: +ve mode-HRTOF-ESI-mass spectrum of lycorine (2). Figure S6: ${ }^{1} \mathrm{H}$ NMR spectrum of lycorine (2). Figure S7: ${ }^{13} \mathrm{C}-\mathrm{NMR}$ spectrum of lycorine (2). Figure S8: DEPT-135 spectrum of lycorine (2). (Supplementary Materials)

\section{References}

[1] IARC, Latest Global Cancer Data: Cancer Burden Rises to 18.1 Million New Cases and 9.6 Million Cancer Deaths in 2018, International Agency for Research on Cancer, Press release N 263, World health organization, Geneva, Switzerland, 2018, https://www.iarc.fr/wp-content/uploads/ 2018/09/pr263_E.pdf.

[2] P. Boyle, T. Ngoma, R. Sullivan, and O. Brawley, "Cancer in Africa: the way forward," Ecancermedicalscience, vol. 13, p. 953, 2019.

[3] A. Jemal, F. Bray, D. Forman et al., "Cancer burden in Africa and opportunities for prevention," Cancer, vol. 118, no. 18, pp. 4372-4384, 2012.

[4] A. Amin, H. Gali-Muhtasib, M. Ocker, and R. SchneiderStock, "Overview of major classes of plant-derived anticancer drugs," International Journal of Biomedical Sciences, vol. 5, no. 1, pp. 1-11, 2009.

[5] K. I. Block, C. Gyllenhaal, L. Lowe et al., "Designing a broadspectrum integrative approach for cancer prevention and treatment," Seminars in Cancer Biology, vol. 35, pp. S276S304, 2015.

[6] Y. Vaghasiya, R. Dave, and S. Chanda, "Phytochemical analysis of some medicinal plants from Western region of India," Research Journal of Medicinal Plant, vol. 5, no. 5, pp. 567-576, 2011.

[7] D. J. Newman and G. M. Cragg, "Natural products as sources of new drugs over the last 25 years," Journal of Natural Products, vol. 70, no. 3, pp. 461-477, 2007.

[8] G. M. Cragg and D. J. Newman, "Plants as a source of anticancer agents," Journal of Ethnopharmacology, vol. 100, no. 12, pp. 72-79, 2005.
[9] A. L. Demain and P. Vaishnav, "Natural products for cancer chemotherapy," Microbial Biotechnology, vol. 4, no. 6, pp. 687-699, 2011.

[10] N. T. Tram, T. Titorenkova, V. Bankova, N. Handjieva, and S. S. Popov, "Crinum L. Amaryllidaceae," Fitoterapia, vol. 73, no. 3, pp. 183-208, 2002.

[11] Z. Jin, "Amaryllidaceae and sceletium alkaloids," Natural Product Reports, vol. 30, no. 6, pp. 849-868, 2013.

[12] D. Katoch, S. Kumar, N. Kumar, and B. Singh, "Simultaneous quantification of Amaryllidaceae alkaloids from Zephyranthes grandiflora by UPLC-DAD/ESI-MS/MS," Journal of Pharmaceutical and Biomedical Analysis, vol. 71, pp. 187-192, 2012.

[13] C. C. Presley, P. Krai, S. Dalal et al., "New potently bioactive alkaloids from Crinum erubescens," Bioorganic \& Medicinal Chemistry, vol. 24, no. 21, pp. 5418-5422, 2016.

[14] T. Teklehaymanot, "Ethnobotanical study of knowledge and medicinal plants use by the people in Dek Island in Ethiopia," Journal of Ethnopharmacology, vol. 124, no. 1, pp. 69-78, 2009.

[15] F. Tamiru, W. Terfa, E. Kebede, G. Dabessa, K. Roy, and M. Sorsa, "Ethnoknowledge of plants used in veterinary practices in Dabo Hana district, West Ethiopia," Journal of Medicinal Plant Research, vol. 7, no. 40, pp. 2960-2971, 2013.

[16] S. Piszczan, D. Desalegn, H. Petros et al., "Clinical characteristics and survival of patients with malignant ovarian tumors in Addis Ababa, Ethiopia," Oncologist, vol. 24, no. 6, pp. 303-311, 2019.

[17] Globocan, Ethiopia, Global Cancer Observatory, 2018, International Agency for Research on Cancer, World health organization, Lyon, France, 2018, https:/gco.iarc.fr/today/data/ factsheets/populations/231-ethiopia-fact-sheets.pdf.

[18] S. Wang, C. Meades, G. Wood et al., "2-Anilino-4-(thiazol-5yl)pyrimidine CDK inhibitors: synthesis, SAR analysis, X-ray crystallography, and biological activity," Journal of Medicinal Chemistry, vol. 47, no. 7, pp. 1662-1675, 2004.

[19] S. Osnowski, P. Li, S. K. Basnet et al., "Unveiling new chemical scaffolds as Mnk inhibitors," Future Medicinal Chemistry, vol. 8, no. 3, pp. 271-285, 2016.

[20] S. Tadesse, M. Yu, L. B. Mekonnen et al., "Highly potent, selective, and orally bioavailable 4 -thiazol- $N$-(pyridin-2-yl) pyrimidin-2-amine cyclin-dependent kinases 4 and 6 inhibitors as anticancer drug candidates: design, synthesis, and evaluation," Journal of Medicinal Chemistry, vol. 60, no. 5, pp. 1892-1915, 2017.

[21] L. Lam, S. Takaidza, and M. Pillay, "Preliminary phytochemical screening of crude extracts from the leaves, stems, and roots of Tulbaghia violacea," International Journal of Pharmacognosy and Phytochemical Research, vol. 9, no. 10, pp. 1300-1308, 2017.

[22] E. E. Elgorashi, "Alkaloids from three South African crinum species," Ph.D. thesis, University of Natal, Pietermaritzburg, South Africa, 2020, https://researchspace.ukzn.ac.za/bitstream/ handle/10413/10254/Elgorashi_Esameldin_E_2000.pdf?sequence $=1$ \&isAllowed $=\mathrm{y}$.

[23] O. B. Abdel-Halim, T. Morikawa, S. Ando, H. Matsuda, and M. Yoshikawa, "New crinine-type alkaloids with inhibitory effect on induction of inducible nitric oxide synthase from Crinum yemense," Journal of Natural Products, vol. 67, no. 7, pp. 1119-1124, 2004.

[24] R. B. Giordani, C. O. R. Junior, J. P. de Andrade et al., "Lycorine derivatives against Trichomonas vaginalis," Chemical Biology \& Drug Design, vol. 80, no. 1, pp. 129-133, 2012.

[25] A. Evidente, M. Rosaria Cicala, I. Giudicianni, G. Randazzo, and R. Riccio, ${ }^{c 1} \mathrm{H}$ and ${ }^{13} \mathrm{C}-\mathrm{nmr}$ analysis of lycorine and 
$\alpha$-dihydrolycorine," Phytochemistry, vol. 22, no. 2, pp. 581-584, 1983.

[26] S. Ghosal, A. Shanthy, and S. Singh, "Isocraugsodine, an $n$ arylidenephenethylamine from Crinum asiaticum and its $e \sim z$ isomerism," Phytochemistry, vol. 27, no. 6, pp. 1849-1852, 1998.

[27] J. J. Nair, W. E. Campbell, D. W. Gammon et al., "Alkaloids from Crinum delagoense," Phytochemistry, vol. 49, no. 8, pp. 2539-2543, 1998.

[28] J. Boik, Natural Compounds in Cancer Therapy, Oregon Medical Press, Princeton, MN, USA, 2001.

[29] Z. Cao, D. Yu, S. Fu et al., "Lycorine hydrochloride selectively inhibits human ovarian cancer cell proliferation and tumor neovascularization with very low toxicity," Toxicology Letters, vol. 218, no. 2, pp. 174-185, 2013.

[30] A. K. Zhang, J. Bastida, C. Codina, F. Viladomat, R. Brun, and S. C. Chhabra, "Augustamine type alkaloids from Crinum kirkii," Phytochemistry, vol. 65, no. 23, pp. 3143-3149, 2004.

[31] P. Wang, H.-H. Yuan, X. Zhang, Y.-P. Li, L.-Q. Shang, and Z. Yin, "Novel lycorine derivatives as anticancer agents: synthesis and in vitro biological evaluation," Molecules, vol. 19, no. 2, pp. 2469-2480, 2014.

[32] M. A. Arai, R. Akamine, S. K. Sadhu, F. Ahmed, and M. Ishibashi, "Hedgehog/GLI-mediated transcriptional activity inhibitors from Crinum asiaticum," Journal of Natural Medicines, vol. 69, no. 4, pp. 538-542, 2015.

[33] P. Khumkhrong, K. Piboonprai, W. Chaichompoo et al., "Crinamine induces apoptosis and inhibits proliferation, migration, and angiogenesis in cervical cancer SiHa cells," Biomolecules, vol. 9, no. 9, p. 494, 2019.

[34] D. Theys, A. Andolfi, G. Goietsenoven et al., "Lycorine, the main phenanthridine amaryllidaceae alkaloid, exhibits significant anti-tumor activity in cancer cells that display resistance to proapoptotic stimuli: an investigation of structure-activity relationship and mechanistic insight," Journal of Medicinal Chemistry, vol. 52, no. 20, pp. 62446256, 2009.

[35] R. Dasari, L. M. Y. Banuls, M. Masi et al., "C1, C2-ether derivatives of the amaryllidaceae alkaloid lycorine: retention of activity of highly lipophilic analogues against cancer cells," Bioorganic \& Medicinal Chemistry Letters, vol. 24, no. 3, pp. 923-927, 2014. 